\title{
PSYCHOANALYTICAL INTERPRETATION OF THE INTERSEX RELATIONS IN S. PROTSYUK'S NOVEL "INFECTION"
}

\author{
Melniichuk Vladyslav \\ Postgraduate Student \\ ORCID ID 0000-0002-9267-3784 \\ Zhytomyr State University named after I. Franko \\ 40, Velyka Berdychivska St, 10002, Zhytomyr, Ukraine \\ wmelnijczuk@gmail.com
}

The article is devoted to the analysis of the artistic world of the S. Protsyuk's novel "Infection" The selected a priori schemes-matrices in the research help to find the complexes around which the author's imagination begins to work and to create the artistic world of the future work. The partially explained process of formation of the writer's novels helped to outline certain unconscious components and supplanted desires of the artist. The analysis of the character's dreams, his fantasies and visions reveals to the recipient the undisguised archetype of the writer's Anima. The considering hero's unconscious states around this matrix explain us several complexes. The identified features make it possible to assert their presence in creator's person.

Our creative search involves the explanation of the intersex relations of the characters with the help of the archetype of Anima, which forces the person to unconscious actions. It includes: attraction to persons of the opposite sex, neurotic perception of reality, donjuanism, the emergence of fantasies and dreams, which opens a broader picture of the psyche of the individual. This archetype often finds its expression in the work and is clearly manifested in the love lines of the novel, so it would be wrong to ignore it.

The comparison of the features of the protagonist's wife and his mother shows us the similarity and correspondence of the heroines. Analysis of the dreams and fantasies of the hero indicates that the hero lived at the expense of women. This statement is confirmed by the interpretation of the following dreams and fantasies in the article. The consideration of the childhood reveals to us the main reason for the betrayal of the hero, because there we find two complexes: the Oedipus complex and the Mother complex. The detected complexes become the cause of neurotic perception of reality and unstable psyche. complex.

Key words: archetype, collective unconscious, Ego, Anima, Oedipus complex, Mother

\section{Introduction}

S. Protsyuk's prose can be considered in several main aspects - as psychological, as existential, as social, as romantic, as philosophical, but the most important feature of this author's prose is psychologism. This forces some readers to re-read the novels several times, while others reject these works of art altogether, pointing to "difficult" writing and difficult perception. The resolving of this conflict between fans and adversaries involves a detailed study of the artist's work. The first novel that needs deeper analysis is the novel "Infection", because from this novel it begins the perception of the writer's prose by the literary critics. Given that S. Protsyuk continues to work fruitfully, and his novels find their readers (the last of which is "Fingers Between the Sand" (2020). So, the interest in the studying of the artist's work is growing. Despite the existence of many researchers and reviewers, we do not find psychoanalytic research to novel "Infection". The study of psychological works through psychoanalytic explanation and deciphering involves the identification of the deep foundations of the creative process, the deepening of the meaning of the novels. This and all of the above make our scientific research topicality.

(C) Melniichuk Vl., 2020 
The aim of the study is to interpret the intersex relations between the characters of the novel on the basis of the archetype (Anima), which exists independently of the individual's will and internally motivates him to action. This analysis will help us to identify the complexes that are inherent in the hero and in the creator. These are the key components around which fantasies grow, which later pass or become the basis of a work of art. To achieve this goal we need to solve several tasks:

characters;

$>$ to find out the influence of the image of the mother (wife) on the male Anime;

explain the unconscious actions of the main characters using the archetype of of view;

interpret the dreams and fantasies of the protagonist from a psychological point formed;

$>$ to single out the complexes and to find out under the influence of what they are

\section{Materials and methods of research}

The features of our study indicate the using of the psychoanalytic literature and the analyzed rethinking of the reviewers' views. It is quite natural to involve the works of the "father of psychoanalysis", Z. Freud, in particular: "Three essays on the theory of sexuality", "Introduction to psychoanalysis", in which we find the explanations of the neuroses and the mental disorders, the ways to understand the dreams, their functions, the human psyche . K.G. Jung's works are also used. Among them we can mention: "Psychology of transference", "Psychology and religion", "Study of the phenomenology of the self", "Soul and myth: six archetypes", "Archetype and symbol". These materials of the Swiss scientist serves as an applied tool for the interpreting of characters' behavior, their motives and unconscious aspirations, dreams, fantasies, delusions.

The literary critics' opinions reinforce the hypotheses about the heroes of the S. Protsyuk's art world. The following works of reviewers were used in scientific research: L. Skoryna "Ordering an Enchanted Labyrinth", O. Solovya "Man Running Over the Abyss", "Apology of Life, Apology of Suffering", B. Pastukha "Allegory of Empty Beauty", L. Kostetska "Complexes in the structure of the psyche of the characters of S. Protsyuk's novel "Totem ", in which we find the researchers' attempt to find out the actions of the characters in the connection with their complexes.

In this study the sources that explain the application of the method of psychoanalysis in literary criticism are indispensable: "Psychoanalysis and literary criticism" N. Zborovska. "Literary psychoanalysis: methodological advice" G. Nikitchina,"Psychoanalytic research in modern literary criticism" S. Natyazhko, "Theory of Literary Research" Z. Mitosek. The involvement of these sources helped to clarify the intersex relations of the characters and to find the complexes of the main character.

The method of research is clearly subordinated to the purpose and objectives of the work. It is a method of psychoanalysis. It is known that this method was established in psychiatry in the early of XX century. The pioneer of the use of this method in the literature can be considered Z. Freud, because in the scientific achievements of the famous Austrian we find the following works: "Dostoevsky and father-murder", "Leonardo da Vinci - Childhood Memory", which revealed the psyche of writers from different angles. The initial task of classical psychoanalysis was to find neuroses, complexes that cause the process of the creating a work of art. This is the so-called psychobiographical method. Another branch of psychoanalysis was the method of psychoanalytic interpretation of the text. This method was developed in the analysis of dreams, fantasies and wit, carried out by Freud in the works "Interpretation of Dreams", "Hallucinations and Dreams in Jensen's" Gradiev "," Poet and Fantasy "," Wit and his relationship to the unconscious "(Zborovska, 2003: 64). Of course, the application of this method will deepen the meaning of the literary text, but the main task of psychoanalysis is to clarify the motives that prompted the author to choose for the image of a material - to reveal the subjective reasons for the writer's imagination. (Nikitchina. 2003: 
14). We can find unresolved contradictions and complexes by the author's consciousness by analyzing the behavior of the characters in the art work.

\section{Discussion}

S. Protsyuk's artistic world is a special phenomenon that reviewers rarely overlook. Various literary critics studied the author's work. Among them there are O. Solovej, who characterizes the prose of S. Protsyuk as one that depicts the values lost by man, $\mathrm{H}$. Bukatchuk and O. Yurchuk, who explain the influence of the postcolonial syndrome on the hero of the writer's novels, R. Kharchuk and I. Bondar-Tereshchenko, who consider the novel from the standpoint of geographical location of the writer, B. Pastukh, who points to the unfortunate characters of the author, E. Baran, who tries to sacralize the work of the artist and S. Sirenko, who notes that the prose of S. Protsyuk is highly intelligent.

L. Kostetska deserves special attention to the interpretation of the author's works by the method of psychoanalysis. In their article "The complexes in the structure of the psyche of the characters of S. Protsyuk's novel "Totem", the researcher analyzes the features of the psychotype of the characters and find out several basic mental complexes: complex love for father, complex of the dissatisfied love, complex loneliness, inferiority complex. The researcher concludes that "the main characters of "Totem" - men, if not broken mentally or nervously, then certainly "over-chipped". Women, meanwhile, are vague characters, but mostly masochistic. We practically do not observe people with normal mental organization here" (Kostetska, 2009: 85). L. Kostetska uses the method of psychoanalysis, but do not operate with concepts: the archetype, the collective unconscious, Anima, Ego, subconscious, sublimation. It should also be noted that the researcher analyzes the novel "Totem", not the novel "Infection".

Despite the available number of studies, none of the researchers turned to the psychoanalytic interpretation of intersex relations and the selection of complexes of the heroes of the S. Protsyuk's novel "Infection". The explaining the character's behavior in relationships with women with the help of the unconscious archetype of Anima will open us road to understand what complexes the character has (respectively, the author).

\section{Presentation of the material}

It is appropriate to consider the first psychological novel in tetralogy - "Infection", which clearly reflects the love line and all the psychological changes to which it leads the characters. The figure of Sava Chornokryl is chosen not by chance, "this character is the most sensitive in the perception of the actual existential problems, in particular the total loneliness of man in the absurd world" (Skorina, 2012). The hero finds himself in an existential collapse, as his views on the state, the economy, a happy life are destroyed, and it is at this time that the love line of his life develops: he marries and has a mistress.

The female images of Mariana and Ivanka, mistress and lawful wife, change the life of the hero, only each of them is different. In the case of Ivanka, after marriage Chornokryl became a "squirrel in a wheel" (Protsyuk, 2012: 45) Accordingly, his worldview changed: "He begans to think with clay and a stretcher" (Protsyuk, 2012: 58). His inflated thoughts about himself also change: "Several times he hammered his fingers, at the end he locked his construction project, the proverb about a shoemaker, a reaper, and a Greek bagpipe is not for him" (Protsyuk, 2012: 66), "he is not a skilled master-laborer, his hands grow from the wrong place" (Protsyuk, 2012: 66). Sava's attitude to money is changing: "these three-damned banknotes, on the surface of which there should be signs of blood and death, crimes and sacrilege, because these banknotes are anti-love" (Protsyuk, 2012: 64), "How to repay debts? All insignificant forgeries and promises are exhausted "(Protsyuk, 2012: 66). It should not be overlooked that Chornokryl becomes spiritually devastated after marriage: "Sava came home twisted like a rag, feeling bouts of the disgust and the anger towards himself - a specialist in the solutions and the trowels..." (Protsyuk, 2012: 58). The hero is tired of everyday life, the constant gray existence: "Sometimes I thought that for his soul is contraindicated disgusting 
awkwardness and uninteresting routine, the impact of which can not be vaccinated" (Protsyuk, 2012: 65).

Sava's betrayal appears in an interesting direction - in the novel it is presented as a confession to a friend - Kirill Orlenko. The protagonist tells of another woman who entered his life: "her hair is black, short, like, you know, a feminist hairstyle, her eyes are dark and big; not a single secret is probably hidden behind those eyes " (Protsyuk, 2012: 97-98). This is a woman who radically changes a man's life. Her image resembles one of the most popular modernist types - the type of fatal woman.

The phenomenon of "fatal woman" (French "la femme fatale") is most often associated with the female image, the main features of which are the ability to manipulate the environment, mostly men through the flirtation. Fatalism (French fatalism, Latin fatalis predetermined by fate) - the belief in the inevitability, fate. The main attributes of a fatal woman are her external attractiveness, unusualness, energy of magnetic, often unmotivated influence on a man, masking of her true inner world and character, adventurous behavior, emotional ecstasy, confidence and self-sufficiency, spontaneous femininity, charisma, awareness of men. For the most part, the intensity of the image of such a woman is associated with a destructive effect on men, who later experience dramatic disappointment associated with the destruction and debunking of their female ideal. A fatal woman is able to change the life and destiny of a man in general, as a result of which the fate of these women becomes fatal (Muranets, 2013: 1). Of course, in our case, this is Mariana.

It is interesting to explain the history of adultery through the system of concepts of the jungian psychoanalysis, in particular through the concept of the psychological projection of the archetypal image of Anima. Psychoanalysis is able to balance all components of the human psyche (Volynka, 1993: 198). Anima is the archetype of a woman in a man. One of the functions of this archetype is the design function. Men under the influence of this unconscious force are capable of a completely different view of the person of the opposite sex. They project on her the features of their "woman" who lives inside them (Jung). The archetype of Anima in a man involves the unconscious superimposition of the features of a man's mother on his chosen one.

The novel traces the closeness between the images of Blackwing's mother and his wife Ivanka. This is read in the way of life of the heroines: "... her mother worked on a collective farm, they lived in poverty, from some of Sava's deaf hints the girl understood that she was below the poverty line" (Protsyuk, 2012: 34). Life was no better for Sava and his wife, who "understood what half-starvation was. She and her mother forgot about the taste of meat, as if some omnipotent uncle from above was engaged in the introduction of widespread violent vegetarianism" (Protsyuk, 2012: 30). Both families lived in poverty. This similar way of life leads to the formation of a similar type of worldviews and psychologies (Jung).

Ivanka and her mother-in-law have similar character traits. A characteristic detail in the description of the heroine is: "The girl is amazed where her Thatcher's strictness..." (Protsyuk, 2012: 31). Such strictness and cruelty to his wife Sava can be traced in science: "Ivanka gnawed books like a rat at any leftover food, chaotically and stubbornly. She knew that no one would help... "(Protsyuk, 2012: 30). These traits of the daughter-in-law, of course, correspond to the character traits of the mother-in-law herself, as described by her author: "Sava's mother is restrained, cruel, her life has hardened" (Protsyuk, 2012: 38). These traits resemble heroines.

Of course, this similarity is also noticeable in views on life. The novel points out that both the daughter-in-law and the mother-in-law are religious. The mother, blessing Sava for family life, says: "Well, where is the consent in the family, and then, as they say, according to the text..." (Protsyuk, 2012: 38). Ivanka often goes to church thinking about her future: "I will go on Sunday evening to our only Greek Catholic church here and I will ask the Lord before the holy images and the holy altar to give strength" (Protsyuk, 2012: 124). The religion is the foundation for the development of a certain moral vision of the world.

The common factor that brings the heroine closer is the isolation from the outside world, the avoidance of social ties. A striking example of this is the scene of the wedding 
discussion: "Savina's mother and sister, as if russian old believers, who were forcibly caught between people, want to say something, but do not dare or are dissatisfied with something" (Protsyuk, 2012: 34). These characters maintain a distance between society and are alien to it. Ivanka feels the same way: "How lonely I am - to complain to anyone, to check myself simply and in a feminine way. There are strangers around - with strangers' interests, strangers' faces, strangers' language " (Protsyuk, 2012: 123). Sava's wife has the same isolation from people as the female part of his family.

The noticed features explain Sava's unconscious attraction to Ivanka, and in more detail, his "inner woman", the projections of which he imposes on his chosen one. The hero replaces his mother with her. There is always a mystical connection between a son and a mother, which can only be overcome by the strong unconscious archetype of Anima (Jung). The prototype scheme is a priori to the human unconscious part of the psyche, destroying this connection only when the son realizes that his inner world contains not only the image of the mother, but also the image of a loved one, daughter, sister.

The internal process of transition is opened to the reader through the dreams of the hero, fantasizing, delusions. The first fantasy of Sava Chornokryl, which we encounter, is " the recipes for a decent family life", from which we learn that the family, according to the hero, "should live in such a way as to travel the world: November 15 to be on premiere of the super-fashionable opera in Vienna, and on November 20 to attend the congress of the most right-wing French party. Cosmopolitan Paris, and in the fancy hall there are maxims about France for the French, the burden of a white man, the greatness of aristocratic blood..." (Protsyuk, 2012: 37). It is quite logical is the question: where the hero may have such visions, because he grew up in a family with low incomes. A possible explanation for this is that the hero has been there before, that this is a normal way of life for him. Sava's appearance suggests associations with the oriental type of male beauty: "narrow black beard... his oriental charms of a brunette" (Protsyuk, 2012: 32),"chubby thirty-three-year-old handsome" (Protsyuk, 2012: 21). His attitude to work: "the owner calmly states that he breaks the virtual contract with Sava, because he has long been tired of it and needs workers, not philosophers" (Protsyuk, 2012: 61). Chornokryl does not have the necessary level of preparation for hard physical labor. The fact that the character did not work hard before marriage is indicated by the following remark: "Sava came home twisted like a rag, feeling bouts of disgust and anger towards himself - a specialist in solutions and trowels" (Protsyuk, 2012: 58). From the text of the novel we learn that Sava was in one of the political parties before marriage, but whether that party could properly provides Chornokryl financially - nothing is stated. It is possible that Sava lived at the expense of women.

The step of betrayal was unconscious, we find it in the text: "I did not believe that it would happen, until the last minute, my daughter emerged so clearly before me, oh, this eternal idiotic disengagement, this incompleteness of life" (Protsyuk, 2012: 102). The images in the human imagination appear when consciousness is weakened and the mind does not control the actions of the individual (Jung). The appearance of the image of the daughter is a glimpse of this consciousness. Savin's Super-Ego, like an unconscious sense of guilt, tries to stop him.

The unconscious is manifested in different variations: it can be represented by the sea, which has no boundaries, the ocean, the forest, in which the end is not visible, the endless sky, the earth as a planet, the wind, its streams (Jung). Its main property is that it appears in fantasies, dreams, as something devoid of boundaries and material nature. Mariana is an expression of this, because she also appears in Sava's mind as a phenomenon that has no limits: "Some kind of mana has seized me, spells and divination" (Protsyuk, 2012: 92). This idea is reinforced by the hero's statement in self-analysis: "This tornado fells on my head and swepts it to the rest, as if I were nailed to a flower, only her eyes and body dream..." (Protsyuk, 2012: 102). Thus, the above-mentioned mental process of invasion takes place, when Sava's consciousness is completely covered by the unconscious. This is indicated by the dreams of the character, in which the image of Mariana appears. The vast majority of dreams are a reflection of the reality we experienced at the time of their emergence or earlier. 
The new passion of the hero is an unconscious force that changes the balance in the psyche of the man, which can be traced in the relationship between the hero and his wife: "And not so looked, and not so cooked, and not so waved, and not so them, and not for him I sleep with my imagination, and I live strangely, without communicating with anyone... Everything irritates and muzzles him, he starts drinking " (Protsyuk, 2012: 124-125). After disturbing this balance, the Chornokryl's Ego behaves even more defensively, confidently, creating a vicious circle that only strengthens his sense of inferiority. In this case, human relations fail, because both the mania for greatness and inferiority complex becomes a path of understanding.

Sava's mental state is evidenced by his dream, which comes to him almost at the end of his meetings with Mariana: "I recently dreamed that I was standing naked, all bruised, tied to a massive piece of iron. And here, on the one hand, Ivanka, on the other - Maryana, two of them are so happy and drunk, laughing until the frost goes out of my skin. Both in rags, Ivanka, however, in white and bloody, and Mariana - in black, rusty. They dance around me, grab my arms, legs and nose. Playing with my genitals, Mariana suddenly takes a pocket knife out of her bosom, laughs so loudly and offers Ivanka to keep my birth in a horizontal position - It will be easier, they say, to cut off. But Ivanka pushes her away, drops the rags, takes a rose out of her womb and hands it to me. Mariana suddenly hangs herself, pounces on a frightened flower and cuts it into pieces, tramples it with her feet, and dripping saliva drips into her face in jerky stains "(Protsyuk, 2012: 146). This dream is an indication of the serious state of mind of the protagonist.

Let's try to explain the psychological nature of this dream and find the answer to the question: what is the Sava's consciousness. Let's follow this in the opinion of the hero: "Mariana has a wonderful family, you don't need much trouble, these are your own people, unless I'm Cain..." (Protsyuk, 2012: 100), "let my phantom, family idyll dissipate, as a material object in the hands of an illusionist" (Protsyuk, 2012: 100). Sava Chornokryl is faced with a choice - to betray or not. After the betrayal, he rebukes himself, realizing that it is a sin. The deviation from moral rules affects the individual adversely, causing neuropsychiatric disorders. The hero, although in a state of "sweet madness", realizes the wrongness of his actions and finds himself at a crossroads - his wife and daughter or Mariana. The search for the right solution to the problem is transferred to the level of the individual unconscious, which finds its expression in a dream.

The symbolism of this dream is also rich in images. Two women appear before us: one in a black dress and the other in white. They personify the positive and shadowy aspects of the unconscious archetype of Anima, act as the personification of the sinful and honest part of Sava's life. This double incarnation also indicates that the hero is in a state of choice. Ivanka symbolically appears in a white dress as a symbol of salvation. White is rich in its purity, because it carries the full range of rainbow colors, which disintegrates when it meets the pure drops of heavenly water. Therefore, in its heavenly-light purity - the harmony of all colors, as in God - the harmony of the whole world (Kalinets). White rags demonstrate the purity of the wife's feelings for her husband, the harmony of their life together. The sign of bloodiness of this outfit indicates the suffering (Kalinets) that Ivanka has to go through while being with the hero. The antithesis of Ivanka is Mariana "in black, rusty rags". Black is a symbol of darkness, evil and death. In general, all the evil forces, the processes of decay and blackout. In our case, the heroine is a destroyer of the harmony of the family hearth. She is the personification of Sava's sinfulness, which explains her appearance in a dream in a black dress.

K.G. Jung points out that white is an expression of consciousness, and dark, black, obscure colors are a transformation of the unconscious (Jung). The heroines act in two parts of the anime of the hero: if the attitude to Ivanka is more conscious, then Mariana acts as an eclipse, as an expression of misunderstanding, attraction to the unconscious. The figure of a naked hero in a dream is also natural, which is nothing but a reflection of his Ego, which, like the hero, has little protection, all bruised, due to the influx of the unconscious and its uncontrolled invasions. 
This dream affects much deeper layers of the collective unconscious: attachment to this piece of iron can be interpreted as the relationship of the Ego to the unconscious part of the psyche, which may fall victim to the protagonist. Sava's consciousness has lost its weight, and he anxiously awaits what will happen next. The appearance of Anima in two guises in front of the defenseless Ego Chornokryl's frightens him even more. The above-mentioned ritual is symbolic and serves as a solution to his conscious problem: what will happen to him next. What Marian plans to do in a dream will destroy Sava as a man, and he will gain signs of femininity. He will lose his male part of the Ego and the consequences will be fatal. His life will break and end in an unknown way. Ivanka's actions save him as a husband, Sofiyka's father. The flower given to him in a dream by his wife is a symbol of faith in a better family life. In Ukrainian mythology, the rose flower is a symbol of love, spiritual perfection, harmony, wisdom and spiritual rebirth. Thus, Anima in a white incarnation obeys the mind, offering the ego of the hero harmonious love, wisdom, and the other black incarnation can not accept this and therefore cuts this symbol into pieces, because it strikes her: (Protsyuk, 2012: 146). The dream indicates that consciousness will still win.

We should not ignore the hero's dream before the birth of his daughter, in which his mother comes to him "and puts his mother's hand on the hot, inflamed Chornokryl's head and asks him to be a good husband and father, not to cause his own indifference, pain or anger. incurable ulcers of a tiny child's soul "(Protsyuk, 2012: 62). Similar dreams appear in fateful moments in a person's life. In the case of Sava, it is a situation of choice: to keep the old way of life or to stop and start living in a new way.

The appearance of this dream can also be explained by returning to the concept of Anima. Sava's mind, his Ego, is in a difficult situation, actively working on possible scenarios: "And two angels are fighting in Sava's soul - black and white" (Protsyuk, 2012: 62). The state of strong nervous load of human consciousness in search of a certain solution leads to the displacement of the problem to the unconscious level - the individual collective unconscious, which is expressed in dreams and fantasies (Jung). This easily explains the fact that Sava has a "hot, inflamed black-winged head" (Protsyuk, 2012: 52). His dream is manifested by the archetype of the Mother, close to the archetype of Anima, which represents guardianship, care, and support for the son (Jung). This image comes to mind at a time when the individual does not know which way would be best to solve the problem. The appearance of the archetype in symbolic form can be quite diverse. It can be both the mother and other females, who are the personification of the fertility, perspective, life, love, mind (Jung). In the case of the main character of S. Protsyuk's novel, it is his mother.

The connection between the Mother archetype and the Anima archetype is quite strong. As noted by K.G Jung: "In a man, the archetype of the Mother is never" pure ", it is always mixed with the archetype of Anima" (Jung). As a result, a man's judgments about a woman are always related to the mother and vice versa. The image of Sava's mother is presented in the work as a source of wisdom, which tries to calm the irritated anime (inner woman) of the son, expediently arranging his further life. This dream also proves the previously stated statement about how Ivanka's features coincide with the features of Sava's mother. The archetype of the Mother instructs the Anime to reduce its influence on the Ego of the hero, "so as not to inflict incurable ulcers on the tiny child's soul" (Protsyuk, 2012: 62), and that the equivalent of the "inner woman" of the son has already been found. As a result, the son should calm down and be a good family man.

The transition from the life of a free man to the life of a family marks a number of changes that have taken place in the psychology of Sava. His previous life ideals, including relationships with women, are destroyed, and as a result, the unconscious of the hero turns on the compensatory function. The consequence of the suppression of aspirations is the emergence of fantasies, which are certain substitutes, varieties of paintings focused on the theme of realization (Mitosek, 2005: 164). These are fantasies of this type: "ten years later he sees himself as a wealthy and wise head of the royal family, which must be supplemented by the future Savich" (Protsyuk, 2012: 66). His ego in fantasy is expanded - the hero thinks that he is the main one in this world ("wealthy and wise"). However, another, no less important, 
reason for the appearance of such a species is that Sava gave birth to a daughter. Experiencing strong emotions creates no less strong influence on the Ego, as a result of which it feels compressed, which leads to images and delusions (Jung). The unconscious part compensates for this compression by inflating the Ego - in fantasy it is represented by the "head of the royal family."

Consideration of the protagonist's childhood is quite motivated, which will add important touches to the description of the hero's psychotype and explain his actions in more depth. According to the protagonist, he grew up without a father: "Nikolai was called his father, who left his mother with small children and moved to Kirovograd region, where he was born, much younger than his mother, passion" (Protsyuk, 2012: 67). The age at which Sava lost his father is also indicated. In the text we find: "His father left the family when the boy was two years old" (Protsyuk, 2012: 37). The mother's complex developed in the Chornokryl's psyche due to the fact that the Oedipus complex was not resolved. This is because the first projections of the object of love in men are made on the mother. After some time in the boy's psyche there comes a moment when he unconsciously tries to replace his father and take his place. In Sava's case, the projections are fixed on the mother, and this complex remains unsolved: the son grows up, becoming more and more aware of his mother's femininity, and, unconsciously, instinctively succumbs to it. In this case, the relationship of identification or resistance and distinction is constantly accompanied by erotic attraction or repulsion, which greatly complicates the situation (Jung). It is the unresolved Oedipus complex that causes further neuroses, psychoses, and unstable psyches. We find the expression of this: "Get rid of reflection, Savo, don't flirt with the mental processes, this can get out of the hands of Western golden youth, alcoholics in the preprotein state, at the very least - the writer "(Protsyuk, 2012: 62). The hero had no projections on his father, which did not form a castration complex and did not lead to identification with the head of the family. In the end, he did not learn the values and morals of family life (Freud, 1989: 95). Proof of this is his attitude towards his family.

This conclusion reinforces all the above reasons for Sava's actions and behavior. His betrayal is explained by this complex, he caused most of his judgments and fantasies. His neurotic states originate here, because, as it turned out, the hero has not completely solved the Oedipus complex. The mother's complex can also explain the presence of Anima in a dream in dark and light guises, his dream before the birth of his daughter, the fatal influence of Mariana on him, the loss of inner harmony, family idyll, neurotic experiences, broken life.

\section{Conclusions and prospects}

The article analyzes the influence of a female character on a male one, the changes he underwent after marriage and during his relationship with Mariana. The question of the internal psychological reason for the search for Sava's mistress, which is solved by considering the unconscious part of the hero's psyche, is explained.

The analysis of the unconscious archetype of Anima found that the Ivanka's image motivated Sava's dream before the birth of her daughter. The appearance of the mother in this dream also serves as an indication that the equivalent of the inner woman has already been found. A study of Sava's fantasy about different women showed that the character lived with different women and at their expense before marriage (donjuanism). After frequent "invasions", Anima of the hero is released, which leads to adultery with Mariana, the incomprehensible influence of which can be interpreted as the invasion of the unconscious.

Going deeper into the childhood of the hero, we find the life without parental care. This means that the Oedipus complex was not resolved and the hero formed the Mother complex, a psychotype of a donjuan. This state of mental life leads to neurosis and is perhaps the main cause of Ego instability. The Mother complex forces to look for the mother in every woman, which provokes the hero to betray and further search. Psychoanalytic interpretation of the hero's behavior and the complexes, found in his unconscious Oedipus and the Mother complex, make it possible to hypothesize the existence of these complexes in the author of 
the novel. This hypothesis still needs to be proven and is the starting point for further research.

\section{СПИСОК ВИКОРИСТАНИХ ДЖЕРЕЛ}

Зарубіжна філософія, 1993 - Зарубіжна філософія XX cm. / Під ред. Г.І. Волинки. К. Довіра, 1993. 239 с.

Зборовська, 2003 - Зборовська Н.В. Психоаналіз і літературознавство: посібник / Н.В. Зборовська. К.: Академвидав, 2003. 392 с.

Калинець - Калинець I. Символіка кольорів [Электрон. ресурс]. - Режим доступа: http://about-ukraine.com/index.php?text=363

Костецька, 2009 - Костецьька Л. Комплекси в структурі психіки персонажів роману С. Процюка «Тотем» / Л. Костецька. Вісник Запорізького національного університету. 2009. №1. С. 82-85

Мітосек, 2005 - Мітосек 3. Теорія літературних досліджень / Переклав 3 польської Віктор Гуменюк, науковий редактор В.І.Іванюк. Сімферополь: Таврія, 2005. 408 c.

Муранець, 2013 - Муранець T. Портрет фатальної жінки у прозі Івана Франка / T. Муранець. Вісник Львівського університету. Серія філологічна. 2013. Випуск 58. С. 82-97.

Нікітчина, 2003 - Нікітчина Г.Д. Літературознавчий психоаналіз: методичні поради. Житомир, 2003. 24c.

Процюк, 2012 - Процъюк C. Інфекція. Жертвопринесення. Тотем / С. Процюк. ІваноФранківськ: «Тіповіт», 2012. 562 с.

Скорина, 2012 - Скорина Л. Замовляння зачаклованого лабіринту [Электрон. ресурс]. Режим доступа:

http://bukvoid.com.ua/events/pesentation/2012/09/02/113624.html

Фрейд - Фрейд 3. Три очерка по теории сексуальности [Электрон. ресурс]. - Режим доступа: http://lib100.com/book/psychoanalis/3_essays_about_theory_of_sexuality

Фройд, 1989 - Фройд 3. Введение в психоанализ: Лекции. М:. Наука. 1989. 456 с.

Юнг - Юнг К.Г. Архетип и символ [Электрон. ресурс]. - Режим доступа: https://www.litmir.me/br/?b=104497\&p=1

Юнг - Юнг К.Г. Душа и миф: шесть архетипов [Электрон. ресурс]. - Режим доступа:https:// https://bookap.info/clasik/yung dusha_i mif shest arhetipov/

Юнг - Юнг К.Г. Исследование феноменологии самости [Электрон. ресурс]ю - Режим доступа: $\quad$ https://www.rulit.me/books/aion-issledovanie-fenomenologiisamosti-read-520001-1.html

Юнг - Юнг К.Г. Психология и религия [Электрон. ресурс]. - Режим доступа: http://lib100.com/book/common_psychology/psihologiya_i religia/html/

Юнг - Юнг К.Г. Психология переноса [Электрон. ресурс]. - Режим доступа: http://lib100.com/book/psychoanalis/psihologiya_perenosa/html/

\section{REFERENCES}

Voly`nky, 1993 - Zarubizhna filosofiya XX st. / Pid red. G.I. Voly`nky` - Kঃ.Dovira, 1993. $239 \mathrm{~s}$.

Zborovs`ka, 2003 - Zborovs`ka N.V. Psy`xoanaliz i literaturoznavstvo: posibny`k / N.V. Zborovs`ka. - K.: Akademvy`dav, 2003. - 392 s.

Kaly`necz - Kaly`necz` I. Sy`mvolika kol`oriv [Эlektron. resurs]. - Rezhy`m dostupa: http://about-ukraine.com/index.php?text=363

Kostecz`ka, 2009 - Kostecz`ka L. Kompleksy` v strukturi psy`xiky` personazhiv romanu S. Procyuka «Totem»/ L. Kostecz`ka, // Visny`k Zaporiz`kogo nacional`nogo universy`tetu. -2009 . $-\# 1$. - S. 82-85 
Mitosek, 2005 - Mitosek Z. Teoriya literaturny`x doslidzhen` / Pereklav z pol`s`koyi Viktor Gumenyuk, naukovy`j redaktor V.I.Ivanyuk. - Simferopol`: Tavriya, 2005. $408 \mathrm{~s}$.

Muranecz`, 2013 - Muranecz` T. Portret fatal`noyi zhinky` u prozi Ivana Franka / T. Muranecz`// Visny`k L`vivs`kogo universy`tetu. - Seriya filologichna. - 2013. - Vy`pusk 58. - S. 82-97.

Nikitchy`na, 2003 - Nikitchy`na G.D. Literaturoznavchy`j psy`xoanaliz: metody`chni porady`. - Zhy` tomy`r, 2003.- 24s.

Procyuk, 2012 - Procyuk S. Infekciya. Zhertvopry`nesennya. Totem / S. Procyuk. - IvanoFrankivs`k: «Tipovit», 2012. - 562 s.

Skory`na, 2012 - Skory`na L. Zamovlyannya zachaklovanogo labiry`ntu [Эlektron. resurs]. Rezhy`m dostupa: http://bukvoid.com.ua/events/pesentation/2012/09/02/113624.html

Frejd - Frejd Z. Try` ocherka po teory`y` seksual`nosty` [Эlektron. resurs]. - Rezhy`m dostupa:

http://lib100.com/book/psychoanalis/3_essays_about_theory_of_sexuality

Frojd , 1989 - Frojd Z. Vvedeny`e v psy`xoanaly`z : Lekcy`y`. - M. : Nauka. 1989. - 456s.

Yung - Yung K.G. Arxety`p y` sy`mvol [Эlektron. resurs]. - Rezhy`m dostupa: https://www.litmir.me/br/?b=104497\&p=1

Yung - Yung K.G. Dusha y` my`f: shest` arxety`pov [Эlektron. resurs]. - Rezhy`m dostupa:https:// https://bookap.info/clasik/yung_dusha_i_mif_shest_arhetipov/

Yung - Yung K.G. Y`ssledovany`e fenomenology`y` samosty` [Эlektron. resurs]. Rezhy`m dostupa: https://www.rulit.me/books/aion-issledovanie-fenomenologii-samostiread-520001-1.html

Yung - Yung K.G. Psy`xology`ya y` rely`gy`ya [Эlektron. resurs]. - Rezhy`m dostupa: http://lib100.com/book/common_psychology/psihologiya_i_religia/html/

Yung - Yung K.G. Psy`xology`ya perenosa [Эlektron. resurs]. - Rezhy`m dostupa: http://lib100.com/book/psychoanalis/psihologiya_perenosa/html/

Received: 12 June, 2020 
